вжито неконкретний прикметник happy, який призводить до трансдериваційного пошуку (пошуку власного досвіду, який допоміг би адресатові зрозуміти слова адресанта [3, с. 155].

Неконкретні слова різних класів $є$ невід'ємною складовою гіпнотичного дискурсу, вони використовуються майже в кожній репліці, що продукує гіпнотерапевт. В вибірці було нараховано 6577 випадків використання неконкретних слів. Серед них домінантні позиції займали номіналізації (38\%), неконкретні прикметники (21\%) і неконкретні дієслова (26\%). Частотність неконкретних іменників є незначною (8\%), що можна пояснити великою кількістю номіналізацій, які в більшості випадків виражено іменниками. $10 \%$ від загальної кількості неконкретних слів складають інші типи, що було перераховано вище. Основою гіпнотичних текстів є іменники, прикметники й дієслова, які призводять до активізації трансдериваційного пошуку.

\title{
Література:
}

1. Гинзбург М.Р., Яковлева Е.Л. Систематический курс эриксоновского гипноза. М.: Московский психолого-социальный институт, 2008. $312 \mathrm{c}$.

2. Плигин А., Герасимов А. Руководство к курсу НЛП-Практик. М.: КСП+, 2000. $578 \mathrm{c}$.

3. Bandler R., Grinder J. Patterns of the Hypnotic Techniques of Milton H. Erickson, M.D. Volume I. Scotts Valley: Grinder \& Associates, 1975. 269 p.

DOI https://doi.org/10.30525/978-9934-588-90-7-38

\section{STRATEGIES OF WRITING ESSAYS}

\author{
Kirillova M. D. \\ Candidate of Science in Philology (PhD), \\ Associate Professor at the Department of Theory \\ and Practice of Translation \\ Odesa I. I. Mechnikov National University \\ Odesa, Ukraine
}

This article deals with the strategies how to form words, how to put words together into sentences, and how to punctuate those sentences.

Writing is a means of communication you must consciously learn. And part of what makes it hard to learn is that written words usually have to express your meaning in your absence, have to "speak" all by themselves. When you speak face to face with a listener, you can communicate in many different ways. You 
can raise or lower the pitch or volume of your voice to emphasize a point, you can grin, frown, wink or shrug; you can use your hands to shape out a meaning when you don't quite have the words to do it. But in writing you have to communicate with-out facial expressions, gestures, or body English of any kind. You have to speak with words and punctuation alone.

Writing is a solitary act. When you talk, you normally talk to someone who talks back, who raises questions, who lets you know whether or not you are making yourself clear. But when you write, you work alone. To write well, you have to anticipate the reactions of a reader you cannot see or hear.

But writing does have one big advantage over speaking. It gives you time to think, to try out your ideas on paper, to choose your words, to read what you have written, to rethink, revise and rearrange it, and most importantly, to consider its effect on a reader. Writing gives you time to find the best possible way of stating what you mean. And the more you study the craft of writing, the better you will use your writing time.

Good writing requires a working knowledge of grammar, a basic command of the rules that govern the forming of a sentence. To avoid conflict with the (non-linguistic) idea of a sentence as something that starts with a capital letter and ends with a full stop, some linguists introduce the more precise term "clause". This term has a specific meaning: it's a sentence that contains one predicate $[3,69]$. But good writing is more than the act of obeying grammatical rules. It is also the art of using rhetoric - of arranging words, phrases, sentences, and paragraphs in such a way as to engage and sustain the reader's attention.

For example:

He really never crystallized mentally (ET).

The respectability of the party was portentous (ET).

The silences no longer mattered (ET).

As these examples show, the sentence is at once the basic unit of writing and the basic source of its rhetorical effects. A good sentence not only takes its place with other sentences but also makes a place for itself, striking the reader with its own special clarity and force. So, you should bear in mind how to maximize the rhetorical impact on every sentence you write.

You do not normally write single sentences in isolation. You write them in sequence, and rhetoric is the art of making that sequence effective - of moving from one sentence to another in a paragraph, and from one paragraph to another in an essay. It is the art of sustaining continuity while continually moving ahead, of developing a descriptive, a narrative, an explanation, or an argument in such a way as to take the reader with you from beginning to end.

We have no single answer to where writing starts. But since writing originates from somewhere in the mind, your first task to find a way into your 
mind and then out again so that you can bring back the news locked up inside you, waiting to be broadcast and published.

To write effectively about memories, opinions, perceptions, images, emotions or facts, you must not only find and name it, you must also connect it with related ideas and make patterns of meaning from the connections. One of the best ways of doing so is branching. Branching starts with a single word or phrase and grows from there by a process of association. Since all main branches radiate from one key term, branching is a process of exploring its implications, of seeing the range and variety of thoughts it can evoke, of moving from the general to the specific. "So branching is a way of organizing as well as discovering your ideas - a way of brainstorming and patterning at the same time" $[1,17]$.

If you are asked to write a paper on a specified topic, one good way of starting is to consider how you might connect the topic to your own interests and experience. If you've ever had a job, you've had the chance to see how someone else runs a business. Personal experience can be just what you need to find your way into a topic, and you can use branching to help you discover your personal connections to it. While moving to topics outside your personal experience, you will often find conflicts of opinion or belief. Don't worry about spelling, punctuation or grammar. Branching will help you see how one idea leads to another and how the return to the main idea stimulates you further in organizing an essay [2].

One of the biggest obstacles to the success of a short essay is a broad topic. When you fill up a paper with generalizations, you leave yourself no space to think and discover or to use your own experience. If you can define a particular topic in terms of your own experience, you have already begun reducing it to a manageable size. But even as you connect it to your own experience, you should try to isolate and identify a piece of it, to make your topic as precise and specific as possible.

Once you have outlined your topic, you can begin to discover its possibilities by exploring it in three different aspects as a particle, as a wave and as part of a field.

1. To explore the topic as a particle is to explore it all by itself, selfcontained and fixed, isolated for special scrutiny.

2. To explore the topic as a wave is to see it as part of a process, to ask how it came to develop in time and what resulted from it.

3. To explore the topic as part of a field is to consider its relation to other relevant topics. 
Another way of generating ideas about a topic is to dramatize it. If you think of your topic not as an object but as an action, you can dramatize it with basic questions.

The more questions you raise, the more deeply you will penetrate your topic/ When you dramatize your topic with questions, you are decisively beginning to investigate it. All of the questions you ask can help you generate material, and a good deal of this material may find its way into your essay. But just as you need to define your topic as specifically as possible, you also need a basic question to help your define the key problem or conflict you will try to resolve. Focusing on a basic question you can take a decisive step forward in generating an essay.

\title{
References:
}

1. Heffernan, James A.W., Lincoln John E. Writing. A College Handbook. Third Edition. W.W. Norton \& Company. New York London, 1990. Printed in the USA. $716 \mathrm{p}$.

2. MacDonald Susan Peck. Problem Definition in Academic Writing. College English 49, 1987. Pp. 315-331.

3. Tallerman Maggie. Understanding Syntax. Second Edition. London, 2005. $266 \mathrm{p}$.

4. Fowles J. The Ebony Tower. London: Granada publishing, 1974. 115 p. (ET).

DOI https://doi.org/10.30525/978-9934-588-90-7-39

\section{ПРОСОДІЯ ЖІНОК 3 ВИСОКИМ ПРОФЕСІЙНИМ СТАТУСОМ}

\author{
Коваль Н. О. \\ кандидат філологічних наук, \\ доцент кафедри іноземних мов гуманітарних факультетів \\ Одеський начіональний університет імені I. I. Мечникова
}

м. Одеса, Україна

Мета дослідження полягає у виявленні особливостей просодичної реалізації жіночого мовлення з точки зору відображення в ній маркерів гендерної приналежності та високого професійного статусу. Об'єктом дослідження $є$ спонтанні монологічні висловлювання статусних британських жінок 3 різних професійних областей, реалізовані в рамках інтерв'ю. Предметом дослідження є просодичні характеристики мови, 